\title{
Indigenous conflict management and resolution mechanisms on rangelands in pastoral areas, Ethiopia
}

\author{
Mohammed Mussa $^{1{ }^{*}}$, Habtamu Teka $^{1}$ and Ahmed Aliye ${ }^{2}$ \\ ${ }^{1}$ Department of Animal and Range Science, Madda Walabu University, Bale-Robe, Ethiopia. \\ ${ }^{2}$ Department of Rural Development and Agricultural Extention, Madda Walabu University, Bale-Robe, Ethiopia.
}

Received 11 June, 2017; Accepted 8 August, 2017

\begin{abstract}
Conflict resolution and peace building mechanisms remain problematic for most societies in Africa including those in Ethiopia, as most of them are trying to imitate western modalities rather than using their own indigenous institutions. Indigenous conflict resolution and management are proven as less complex and time saving, and participating parties in conflict solve their own problems and handle their affairs in a relative ways more acceptable to them. However, the role this important institutions play in solving the disputes is becoming weak with time. In-depth understanding of the conflicts, indigenous conflicts resolution and management mechanisms, and designing holistic strategies and approaches for addressing the conflicts are very crucial. Therefore, this study reviewed indigenous rangeland conflict management and resolution mechanisms in pastoral areas of Ethiopia. Moreover, it attempts to identify the nature, types, causes, and consequences of conflicts. Conflict has devastating consequences on the lives and livelihoods of pastoral society and the economy of the country as whole. Gain over the control of scarce and strategic resources, particularly water and pasture which is further exacerbated by different factors are among the major causes. Alternative conflict resolution mechanisms need to be strengthened and indigenous customary institutions that regulate access and use of resources need to be empowered. The Elder's council should gain legal recognition, and mechanisms are also needed to allow customary institutions to function in harmony with current modern government structures.
\end{abstract}

Key words: Conflict, conflict management and resolution, Ethiopia, pastoral areas, resource.

\section{INTRODUCTION}

The processes of conflict management in contemporary Africa have been highly centralized with an overemphasis on the role of the modern court; although, such systems may not provide adequate response to the conflicts associated with territorial and natural resource competition, particularly in the utilization of rangeland resources (Kelemework, 2011).

Many scholars reported the effectiveness of customary institutions in improving access to grazing commons for different users when there is variation in resource

*Corresponding author. E-mail: mussamahammed@gmail.com.

Authors agree that this article remain permanently open access under the terms of the Creative Commons Attribution License 4.0 International License 
conditions across space at a given time, which will in turn reduce tension (Haro et al., 2004; Tigist, 2014; Mohammed and Beyene, 2016; Daniel et al., 2017).

Indigenous conflict resolution mechanism is helpful for controlling and resolving conflicts in Africa in general and in Ethiopia in particular (Kinfe, 2014), to this end, it has been reported that the elders' council is proven more capable to adapt the socio-economic culture of the regions examined (Beyene, 2017).

Indeed, elders' council can bridge the gap created by the formal system (which is commonly a formal, westernbased, legal system). However, in Ethiopia, the roles of elders' council in resolution of conflict has been overlooked by government and non-government organizations (Gebresenbet and Kefale, 2012), and considered customary conflict resolutions can be as an alternative when mediation by the formal legal systems fails to fit into the practical local situations (Mohammed and Beyene, 2016). Solving the conflicts using top down approach without understanding the real situation of local community, and disregarding the customary procedures can lead to its escalation rather than resolving the conflicts (Kinfe, 2014).

As in other countries in Africa, Ethiopian pastoralists are some of the most marginalized group and lives under extreme poverty, often having virtually no say over the changes that impact on their lives (Gebresenbet and Kefale, 2012). These communities derive their livelihoods mainly from natural resources. Shrinkage and degradation of these resources in particular, land and water put pastoralists under intense pressure (Bekele, 2010) and, they are increasingly finding themselves fighting for their survival (Bekele, 2010; Tigist, 2014).

As a result, the conflict that causes a loss of human life, loss of livestock, destruction of property and declines in rangeland resources usually happens. The conflicts also affect the development, and provision of crucial services in pastoral areas, by limiting access to rangeland resources. Unless the conflicts are managed wisely, the rangeland resources and pastoral livelihood will continue to deteriorate. Maintaining the peace and sustainable development is one among the top goals of any country; and different institutions are available in managing conflicts to achieve these goals (Beyene, 2017; Daniel et al., 2017).

In pastoral areas of Ethiopia, two institutions are available for dealing with natural resource conflicts that is, the customary and the western (modern) legal institutions. Elder's council has been in use since time immemorial, and is proven for effectiveness in resolving conflicts arising (Beyene, 2017). Different scholars also reported that the management and resolution of conflicts through customary institution remain widely preferred and utilized in different pastoral areas of the country (Bekele, 2010; Kelemework, 2011; Hundie et al., 2008). Despite the accumulated knowledge on the importance of customary institutions, and the call for Ethiopian authorities to support the functioning of traditional access options and successful operation of customary courts (Gemedo et al., 2006; Kinfe, 2014; Beyene, 2017), the commitment from government authorities are very low.

Therefore, the purpose of this paper is to review indigenous conflict management and resolution mechanisms in pastoral areas of Ethiopia. Moreover, the review documents the types, impacts, trends and triggering factors of rangeland resource conflicts. Hopefully, the study will act as a reference for policy makers, researchers, education, and development personnel's, pastoralists, and non-government organizations for the design and implementation of policy strategy, programmes and projects on conflict resolution and livelihood improvement in pastoral areas of Ethiopia.

\section{TYPES OF CONFLICT IN PASTORAL AREAS}

In depth understanding of the types of conflict is very crucial for the intervention of appropriate institution to solve the conflicts wisely. In addition, it provides important information for different actor's on how to support customary institutions for sustainable conflict resolution. Pastoralist conflicts are very complex and take place within several levels of the groups. In general, the violent conflicts in pastoral areas of Ethiopia can occur:

1. Between groups within a clan

2. Between clans of same ethnic groups

3. Between farmers and pastoralists

4. Between pastoralists and investors

6. Between pastoralists and states

6. Between ethnic groups and

7. Trans-border conflict (Kelemework, 2011; Abdisalem, 2012; Anteneh et al., 2014; Fratkin, 2014; Mohammed and Beyene, 2016).

The first two types, between groups within a clan and between clans of same ethnic groups, are a kind of conflict in which group come into conflict due to overlapping interests. In case of the Oromo pastoralists in southern and southeastern Ethiopia, there are three dominant clans namely the Borana, Guji and Gabra, and in case of the Somali pastoralists in eastern Ethiopia, there are three dominant clans namely the Issa, Hawiya and Gedeburs.

In addition, to the conflicts between three Oromo conflicts and three Somali clans, there are the conflicts between different groups of Somali and Oromo of the same clans (Daniel et al., 2017). The third one, is the types of conflict that arises from the lands competition between the pastorals and farmers. The conflicts are between the groups fighting for preserving grazing lands, and those who wants to cultivate the same lands. The shortage of grazing areas forced the pastoralists to move 
into the agricultural areas, and this escalates the conflict. Fertile grazing lands that is, a key pastoral resource was converted to farmlands. This process is often intensified by migration of the highland farmers into the pastoralist areas in the rainy season without the discussion with local community which often results in resistance and eventually conflict (Daniel et al., 2017).

The fourth and fifth conflict types are the types of conflict related with government policy. The appropriation of pastoral lands without consultation of pastorals for state commercial farms and private investors, and marginalizing the pastoralist from fertile grazing lands forced pastoralist to fight with the state and investors (Fratkin, 2014). The conflict between pastoral and state conflicts also arises from the government established conservation areas, and the pastoralist's loss their lands and blame the government for not being a part in benefit sharing's.

The other type of conflict is inter-ethnic conflict in which different ethnic groups come into conflict due to different interests. This form of conflict arises most often between the Oromo and Somali, Afar and Oromo, Afar and Somali, Tigray and Afar, and between Afar and Amhara ethnic groups. There are two major clans of Somali and three Oromo clans in southern and southeastern Ethiopia. The two clans of Somali (Digodia and Gari) and three clans of Oromo (Borana, Guji and Gabra) have come into conflict in one way or the other. For example, there is frequent conflict between the Guji on the one hand, and the Digodi and Gari clans in Guji zone, Liben district on the other hand. There is also conflict in Moyale district between the Digodia on the one hand and the Gabra and Borana on the other.

There is also conflict between the Digodi and Gari of the Somali and the Borana in Arero district. There is also an apparent influx of pastoralists from northern Kenya and southwest Somalia towards Ethiopia in search of water and pasture during complete fail of rain during rain seasons. The new comers and local community come into conflicts and competition for the use of the few perennial water resources and pasture (Abdisalem, 2012).

\section{Impacts of conflict}

Different studies have shown that conflicts are known to cause the loss of livestock and human lives, destruction of household assets, disturbance of schools, and interruption of public services such as health. The impact can manifest itself in terms of reduced access to food; interruptions in education; health care services and trade. There is a reduction in the number of livestock through raids; loss of life and property; lack of water; degeneration of social relationships; forced migration of families and livestock; negative psychological and social impact of death; closure of the borehole; and intensified insecurity leading to reduced outdoor activities; among others these are serious implications to the people already experiencing figures below the national average in health, education and nutrition; the long-term impact being poverty in general (Bekele, 2010; Daniel et al., 2017).

Underutilization and improper conservation of rangelands resources also result from the various violent conflicts. Some of the rangelands are not properly used by different groups in conflict due to conflict of interests (Mohammed and Beyene, 2016). For example, wastage of over 75,000 ha quality rangeland between the Afar and Somali pastoralists were reported during the time of conflicts between the two groups for long period of times. During the conflicts, the movements of pastoralists (strategies for protecting environment from degradation) were also restricted (Mohammed and Beyene, 2016).

Times as well as other resources are also consumed for resolving and managing the conflicts (Daniel et al., 2017). Due to insecurity, people prefer indoor which affect income generating activities and increase in the price of products. Insecurity and fear due to conflicts also affect household food production levels, which in turn leads to increased poverty. Physical insecurity bans people from moving to market places to buy and sell foodstuff, and participate in other income generating commodities. In general, insecurity sparks a whole new cycle of poverty (Bekele, 2010; Tigist, 2014; Daniel et al., 2017).

\section{Trends of the conflicts}

Studies from different corner of the country reported the increase of conflict from time to time (Abdisalem, 2012; Beyene, 2017; Daniel et al., 2017). Many factors contributed to the changed nature of resource conflicts (Bekele, 2010; Kelemework, 2011; Tigist, 2014; Mohammed and Beyene, 2016; Daniel et al., 2017). Some of the most important factors are: loss of access to their key resources, land tenure, presence of two contradicting institutions, droughts, international boundaries, government settlement policy, population growth, water development, insecurity and the weakening of the traditional institutions (Beyene, 2009; Bekele, 2010; Mohammed and Beyene, 2016; Daniel et al., 2017). Any positive innervations on the aforementioned factors would contribute to the management and resolution of the conflicts (Daniel et al., 2017). Therefore, long term conflict resolutions require the commitment of all actors to address the responsible factors for changing nature of resource conflicts.

\section{Informal conflict resolution and management institutions}

For pastoralists, conflict is understood as clash and 
contradictions among ethnic groups or within ethnic groups due to overlapping interests (Kelemework, 2011; Tigist, 2014; Daniel et al., 2017). The countries have various traditional institutions that have their own customary methods to settle the raised conflicts.

The pastoral community including the pastoralists of Ethiopia has well developed conflict resolution mechanism that involves elders and clans leaders to solve disputes in the context of traditional law. The Xeer of Somali, Gadaa system of Oromo and Mada'a of Afar are some of the indigenous conflict resolution and management systems which are governed by an unwritten law that is transmitted from generation to generation orally. Although, there have been some minor differences in their practice and implementation. The Somali, Borana and Afar pastoralists do have their own indigenous institutions led by Ogaz, Abba Gadda and Kedo Abba respectively (Tigist, 2014; Abdisalem, 2012). These pastoral communities have two types of law, the conflict resolution laws that concern intra-ethnic group disputes, and laws concerning interethnic group disputes (Kinfe, 2014).

In Afar, the conflicts between different clans are managed by the Madaa based on customary law and elders. Elders, of the Madda, not representing members in disputes are selected from different clans (Bekele, 2010). The decisions by the council of elders are effective due to the tradition of forgiveness, respect for elders, and the transfer of resources as compensation.

As a result, there are few cases in which conflicts between Afar clans escalate until they need the mediation of outsiders. Madaa was able to effectively manage conflicts between Afars and some of their neighbors in the past (Getachew, 2001; Kinfe, 2014). For example, Afar and Karrayyu used to share institutions that enable them to exchange fugitives, pay compensation, and reduce tensions; that is, if an Afar murdered a Karrayyu (or vice versa), a traditional jury composed of both ethnic groups would handle the case. However, though they still exist to some extent, these shared institutions are no longer influential due to different complex factors.

In the case of Oromo, elders in the community form a dominant component of the customary mechanisms of conflict management (Desalegn et al., 2004; Watson, 2001; Dejene, 2004). This is directly related to sociopolitical functions of Gadaa system, a system of an agegrade classes that succeed each other every eight years in assuming economic, political and social responsibilities. There are five age-grades in a complete Gadaa cycle. Those people who have entered the Luba grade (age range of 40 to 48 ) are called elders.

Therefore, the Lubas (elders) settle disputes among groups and individuals, and apply the laws dealing with the distribution of resources, criminal fines and punishment, protection of property, theft, etc. All Oromo clans have common indigenous conflict resolution mechanisms in which 'Gumma' is the known one. Gumma is a conflict resolution technique related to killing particularly unintentional killing of individual from other or within the same clan. It helps to avoid grievances and revenge that follow the case of killing.

In the case of the Somalis, there is a well-developed, relatively well-structured conflict management mechanism, where the guurti elders act as judges and jury, and their decisions are largely adhered to and respected by the community. The customary law of the Somali is exercised by the well-experienced elders, and the governing unit is the guurti (the council of elders).

The institutions that elders developed are generally respected because elders are seen as trustworthy and knowledgeable people in the community, and are believed to make rational decisions. In addition to solving the conflicts, the elders take measure to prevent conflict through monitoring and punishing individuals who plan to trigger it and through pushing clans to respect the inter clan agreement in place (Abdisalem, 2012)

Even though, different studies underline the importance of indigenous conflict resolution mechanism in achieving sustainable peace, and its preference in pastoral areas of the country (Kelemework, 2011; Abdisalem, 2012; Daniel et al., 2017), indigenous institutions are regarded as an alternative to the formal legal system. The formal (western) legal systems that they are trying to impose on pastoral community have several weak points such as inaccessibility of the formal court system in the pastoral areas and the lengthy process to achieve justice There are also instances where the formal legal system returns the cases to be seen by the elders' council, showing that indigenous conflict management and resolution mechanism bridges the gap created by the formal system (Mohammed and Beyene, 2016).

Formal conflict resolutions base themselves on a fixed code of law, and are hence unlikely to consider long standing social and economic relations among community members. Besides, government legal set ups often culminate in a zero sum outcome (winner-takes-all) because the main purpose is to serve justice through imposed agreements. They never target reconciliation and peaceful coexistence (Kelemework, 2011). Indigenous conflict resolution and management, on the contrary lead to win-win situations as it takes into account the interest of every party. The disputants acknowledge that they have something to gain and something to lose in the end.

Especially, in inter-clan conflict cases, the government legal institutions are regarded as auxiliaries to the local mediation involving elders. Therefore, it is crucial to understand Ethiopian societies potential and actual conflicts in their social context so that the norms, values and beliefs, fears and suspicions, interests and needs, attitudes and actions, relationships and networks are properly taken into account (Kinfe, 2014). 


\section{Relationship between statutory and customary institutions}

Several studies conducted in pastoral areas of the country reported very low interest of different organizations in collaborating with indigenous institutions during the process of enabling the pastoral community solve their problems (Gebresenbet and Kefale, 2012; Kinfe, 2014). Conflicts serve as business opportunities for most of the institutions working in pastoral areas (Bekele, 2010), and they are not fully committed to work with the local community for total avoidance of violence.

Different scholars reported the accumulated indigenous knowledgeable of pastoralists (Oba and Kotile, 2001; Gemedo et al., 2006; Teshome et al., 2010; Beyene, 2017), and call for importance of harnessing them to solve the complex challenges facing pastoral communities and improving their livelihoods. The conflict resolutions through elder's council are among such important knowledge's.

The Elder's council mechanisms were proven for their flexibility and adaptation to the local situation, which in turn bridges the gap created by formal laws (Beyene, 2017). However, there is no pragmatic collaboration between the statutory and customary institutions. Any kind of formal recognition is not given to customary conflict resolution and management (Bekele, 2010; Mohammed and Beyene, 2016; Daniel et al., 2017). Despite the lack of recognition from the state, the customary institutions are playing a crucial role in maintaining smooth relationship in the community, and access to pastoral resources.

Many factors including government economic plan, pastoral policy, land tenure right and other factors are responsible factors for the decline in effectiveness of customary institutions (Clever and Alice, 2014; Fratkin, 2014). Almost all of the government economic plans are the threat to the pastorals due to the relocation and resettlement of populations away from their key resources (Fratkin, 2014), which in turn affects the effectiveness of customary institutions.

The changing administration of communal resources and resettlement of highlander in pastoral areas of the country widens the gaps between the legal and customary institutions. Newcomers increase pressure on the rangeland resources by claiming a substantial share of the existing grazing land rights, and often neglecting the local rules and agreements (Tache and Irwin, 2003; Mohammed and Beyene, 2016; Daniel et al., 2017).

Two contradicting and competing decision are passed by the modern (state) and customary institutions. For example, the newly elected keble administrators (KA) that is, young generation had limited knowledge, less interest to learn and apply the traditional resource management strategies. The wise decision made by customary institutions where opposed by KA.
Groups unsatisfied by the decision of customary institutions may now go to the KA and cancel the elder council decision. This has caused conflicts between generations and disagreements within and among the communities (Mohammed and Beyene, 2016). Due to the aforementioned factors, the important indigenous institutions that is, the elder's councils are under the intense pressures, and we are losing the benefits from these institutions. Legal recognition of customary institution is very crucial, therefore; Ethiopian authorities should support the functioning of traditional access options and successful operation of customary courts to address the conflicts.

\section{CONCLUSIONS AND RECOMMENDATIONS}

The review of the study showed the presence of devastating conflicts which negatively affect the lives of the pastoral in particular and the country in general. The conflicts are between groups within a clan, between clans of same ethnic groups, between farmers and pastoralists, between pastoralists and investors, between pastoralists and states, between ethnic groups and trans-border conflicts. These communities have their own indigenous institutions, and the elders have a social responsibility to maintain peace and stability in the community. The conflict on natural resources increase from time to time due to loss of access to key resources, the land tenure, state administrative systems, drought, international boundaries, settlement, population growth, water development, insecurity, and weakening of customary institutions.

In pastoral traditions, the customary laws are often more important than statutory laws and are relied upon in deciding access rights to rangeland resources and in resolving conflicts. Neglect of these norms and laws may have negative consequences for development policy of the nation in general and the local community who rely on them in particular.

Therefore, a 'systematic combination' of these institutions in the development and management of rangeland resources may facilitate cross-cultural understanding, thereby improving the socio-economic development of the country. However, enforcing the statutory rules on the local community without due consideration for their indigenous norms and values should be avoided on the side of the State.

In dealing with the conflicts in pastoral areas of the country, there is no or loose collaboration between the customary institution and government legal institutions. The government fails to appreciate, collaborate and complement with customary institutions, which in turn diminishes the efficacy and relevance of customary institution in conflict resolutions.

From the present review, the following recommendations 
are forwarded:

1. Strong collaboration and networking between governments' legal and customary institutions of governance is very crucial; particularly, the state should recognize and support the customary courts and enforce their rulings.

2. Detailed understanding of the natural, social, economic, political, and historical contexts of pastoral areas is crucial to provide long lasting solutions.

3. The role of customary institutions in conflict resolution should be spelled out clearly in the rangeland resources policy of the country.

4. Local community should be given a say in the development projects starting right from the planning stage.

5. Conflict management and resolutions should be recognized as part and parcel of pastoral development policies for the development efforts to produce the anticipated impacts on the livelihood of pastoralists.

6. Strong cooperation between the regions and neighboring countries are very crucial for designing institutions to sanction cross regional livestock raiding and facilitating inter-ethnic, cross border resource sharing.

\section{CONFLICT OF INTERESTS}

The authors have not declared any conflict of interests.

\section{REFERENCES}

Abdisalem YM (2012). Study of Conflict among Pastoralists of Ethiopia: A Review of Cases and Experiences. MSc Thesis, Haramaya University, Haramaya, Ethiopia.

Anteneh KG, Melaku B, Teshale W (2014). 'Natural Resource Use Conflict in Bale Mountains'. Intl. J. Biodiversity Conservation 6(12):814-822.

Bekele H (2010). Conflicts between Afar Pastoralists and Their Neighbors: Triggers and Motivations Conflicts between Afar Pastoralists and Their Neighbors: Triggers and Motivations. Int. J. Conflict Violence 4(1):134-48.

Beyene F (2009). Property Rights Conflict, Customary Institutions and the State: The Case of Agro-Pastoralists in Mieso District, Eastern Ethiopia. J. Modern Afr. Stud. 47(2):213-239. Retrieved (https://www.scopus.com/inward/record.uri?eid=2-s2.0-

71749087053\&doi=10.1017\%2FS0022278X09003814\&partner).

Beyene F (2017). Natural resource conflict analysis among pastoralists in Southern Ethiopia. J. Peace Building Dev. 12(1):19-33.
Clever M, Alice N (2014). Social vulnerability and sedentarisation of pastoralists in Gode Zone, Ethiopia. Disaster Adv. 7(6):76-82.

Daniel TG, Tezera G, Fikadu B (2017). Participatory Conflict Analysis: The Case of Pastoralist Groups in South Eastern Ethiopia'. Res. Humanities Soc. Sci. 7(5):39-55.

Fratkin E (2014). Ethiopia's pastoralist policies: Development, Displacement and Resettlement. Nomadic Peoples 18(1):94-114. doi:10.3197/np.2014.180107

Gebresenbet F, Kefale A (2012). Traditional Coping Mechanisms for Climate Change of Pastoralists in South Omo, Ethiopia Knowledge. Indian J. Traditional 11(4):573-579.

Gemedo D, Isselstein J, Maass BL (2006). Indigenous Ecological Knowledge of Borana Pastoralists in Southern Ethiopia and Current Challenges. Intl. J. Sustain. Dev. World Ecol. 13(2):113-130.

Haro G, Doyo O, John GJ, McPeak G, (2004). Linkages between Community, Environmental and Conflict Management: Experiences from Northern Kenya. World Development 33(2):285-299.

Hundie B, Padmanabhan M (2012). The Transformation of the Afar Commons in Ethiopia: State Coercion, Diversification, and Property Rights Change among Pastoralists. http://ageconsearch.umn.edu/bitstream/44360/2/capriwp87.pdf

Kelemework RT (2011). Conflict and Alternative Dispute Resolution among the Afar Pastoralists of Ethiopia. Afr. J. Hist. Cult. 3(3):38-47.

Kinfe S (2014). Dispute Resolution Mechanisms among the Afar People of Ethiopia and Their Contribution to the Development Process. J. Transdisciplinary Res. Southern Afr. 10(3):152-64.

Mohammed A, Beyene F (2016). Social Capital and Pastoral Institutions in Conflict Management: Evidence from Eastern Ethiopia. J. Intl. Dev. 88(2015):74-88.

Oba G, Kotile DG (2001). Assessments of Landscape Level Degradation in Southern Ethiopia: Pastoralists versus Ecologists. Land Degradation Dev. 12(5):461-475.

Teshome A, Abule E, Lisanework N (2010). Traditional Rangeland Resource Utilisation Practices and Pastoralists Perceptions on Land Degradation in South-East. Tropical Grasslands 44:202-212.

Tigist K (2014). Conflicts among Pastoralists in the Borana Area of Southern Ethiopia: The Case of Borana and Garri Conflicts among Pastoralists in the Borana Area of Southern Ethiopia: The Case of Borana and Garri' MSc. Thesis, Haramaya University, Haramaya, Ethiopia. 